
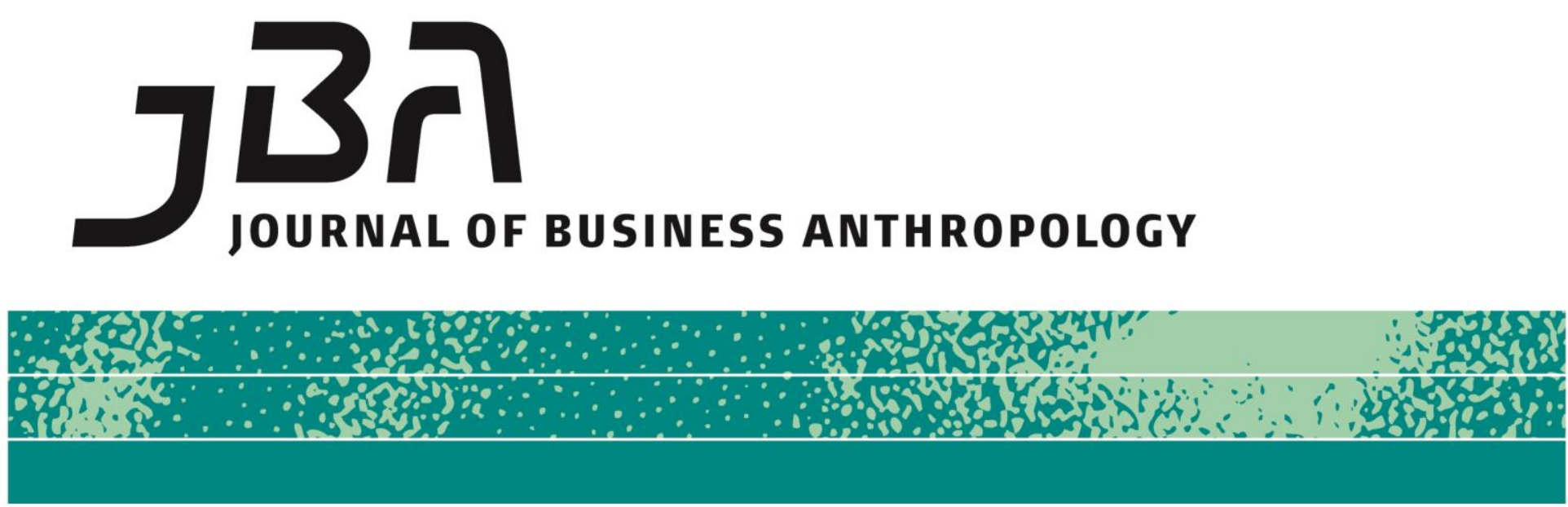

\title{
Fine Chocolate, Resistance, and Political Morality in the Marketplace
}

Maryann McCabe

\begin{abstract}
This article takes the case of fine chocolate to explore resistance in the consumer practice of buying branded products labeled fair trade. Ethnographic research conducted in the US, Europe and Japan at two different points in time indicates that moral satisfaction now joins sensual enjoyment in consumer appreciation of fine chocolate. The article examines social processes shaping fine chocolate into a morally compelling one based on use of fair labor in producing cocoa beans. Looking at the cocoa commodity chain reveals how the marketplace is a locus for challenging status quo. Fine chocolate was transformed from deterritorialized product perceived to come from chocolatiers in West European countries like Belgium and France to reterritorialized product connected to cocoa bean growers in tropical regions of the world. I argue that resistance is not equated with free will located within the individual as an autonomous actor but constitutes a form of agency distributed in an assemblage. Consumers are enmeshed in assemblages that have force or momentum. Examining movements in the fine chocolate assemblage (including chocolate lovers and their senses, chocolate products, producers along the commodity chain, and institutional discourse from media, government and industry) identifies a trajectory of change and correspondence between ethical concern and sensual enjoyment.
\end{abstract}

Page 1 of 28

JBA 4(1): 54-81 Spring 2015

(C) The Author(s) 2015 ISSN 2245-4217

www.cbs.dk/jba 


\section{Keywords}

Resistance, agency, producer-consumer relations, commodity chains

\section{Introduction}

Resistance has proved fertile ground in consumer research because anticonsumption provides a means for examining why people confront corporate marketing ideologies and strategies in the marketplace. Resistance occurs inside and outside the market; outside the market through activist protest and boycotts of specific products or brands (Kozinets and Handelman 1998, Sherry and Kozinets 2007), and inside the market by purchase choices that reject certain products or brands and select others such as fair trade (Dolan 2011, Berlan 2012). These consumer practices of resistance express agency and the political morality of consumption decisions in response to production processes that are considered wrong, harmful or unjustifiable. However, there is limited theory on how resistance enters daily practice and alters producer-consumer relations. This article takes the case of fine chocolate to explore resistance and how agency shifts over time in the dynamic relation between producers and consumers. At the turn of the $21^{\text {st }}$ century, chocolate lovers face something disturbing about the precious cocoa commodity: namely, unfair labor practices and unsustainable farming practices. How does resistance form in the consumer practice of buying fine chocolate that is labeled fair trade?

Pivotal to my interpretation of chocolate's transition to a morally charged commodity is recent media coverage about child labor alleged to exist in cocoa production in West Africa. The publicity highlighted a 2000 BBC documentary, "Slavery: A Global Investigation," describing child slavery on commercial farms in the Ivory Coast, the largest cocoa producing country in the world. The documentary led to a significant amount of news coverage in other media in the UK and US. The Milwaukee Journal Sentinel, for example, published an article entitled, "Slaves feed world's taste for chocolate: captives common in cocoa farms of Africa" (Raghaven and Chatterjee 2001). Of course, this was not the first time that labor injustice was found to exist in the cocoa commodity chain. Reports about bad labor conditions have occurred since the early days of European efforts to develop cocoa production in its colonies (Off 2006, Satre 2005), but the recent media coverage catalyzed response from consumers as well as government and industry. For consumers, the response involves interest in fair trade chocolate. Over the past fifteen years or so, consumer interest in fair trade chocolate has risen at a faster 
pace than it has in the rest of the chocolate market. Ethical concern has joined sensual enjoyment in consumer evaluation and appreciation of fine chocolate products. Since the marketplace is a locus for reproducing social order and challenging the status quo (Slater 1997), I construct an historical transformation of fine chocolate from deterritorialized, class based, luxury product to reterritorialized, morally infused, fair trade product. In the transformative process, social justice becomes embodied in the taste of fine chocolate.

Anthropologists have used the concepts of deterritorialization and reterritorialization in the analysis of globalization and the movement of people, commodities, capital and ideologies around the world. Typically, analysis has looked at flow from core to periphery in the terms of world systems theory (Inda and Rosaldo 2002). A classic ethnographic example employing this kind of analysis is the spread of McDonald's from the United States to East Asia, where the meaning of the McDonald's experience alters and assumes different meanings as it is disembedded from cultural life at the core and integrated into the cultural lives of people in other places (Watson 1997). This article considers a reverse flow of movement: from periphery to core. Cocoa beans grown by farmers in developing countries reach consumers in developed countries in the form of fine chocolate products. Ivory Coast and Ghana are the world's largest cocoa producers, and the EU and the US are the world's major chocolate consuming markets. Until the $21^{\text {st }}$ century, fine chocolate was de-territorialized because consumer perceptions of the commodity chain were truncated, and fine chocolate products were thought to come from Europe where chocolatiers made the confections. It was as if chocolatiers were the only producers in the commodity chain and cocoa farmers did not exist. Fine chocolate was re-territorialized following media coverage beginning in 2000 that alleged use of child labor in cocoa production in West Africa. Institutional response to the media from government and industry brought public attention to the whole commodity chain. Taking into account the entire chain, from farmers growing cocoa beans to consumers eating fine chocolate, helps us to understand how resistance develops in the marketplace.

Resistance has been theorized in terms of two different paradigms: one of domination based on Marxist thinking, and the other of celebration based on consumption as vehicle for self-fashioning and building social relationships (Izberk-Bilgin 2010). Since, in the Marxist approach, the dominance of the market does not allow consumer resistance, I follow the latter (celebration) paradigm relating consumption to identity and sociality, which does accommodate resistance in the marketplace. Social motivation for resistance is influenced by institutional discourse and action. The narrative of fine chocolate presented here indicates how large institutions-including media, government, and industry-impact people's perceptions and reactions to products and brands. As Izberk-Bilgin (2010: 311) reminds us: “... any informed theory of consumer culture and 
resistance should consider the role of institutions in creating, legitimizing and instituting meanings." Looking at the larger institutional context reveals how fine chocolate was transformed into a moral issue facing chocolate lovers in their consumption practice.

To conceptualize the process of resistance in consumer practice, I turn to assemblage theory (Collier and Ong 2005, DeLanda 2006). Assemblage theory provides a way to deal with the complicated notions of agency and resistance in relations between producers and consumers in the global marketplace. The concept of agency cannot be equated simply with resistance or free will (Ahearn 2001). This would locate agency within the individual as an autonomous actor. In defining agency as "the sociocultural mediated capacity to act" (2001: 112), Ahearn recognizes that her definition does not confine agency to humans, although she does not explicate the thought further. Latour (2005) goes further and posits non-human things such as objects and discourse as agents. In the assemblage of fine chocolate, there are chocolate lovers, chocolate products, producers along the cocoa commodity chain, specific institutions (media, government, industry), and discourse about chocolate from these institutions. Fine chocolate products have agency insofar as they have sensual properties, packaging and labels, as well as stores and websites where the products are sold. With fine chocolate marketed under the label of fair trade, the labels contain moral force because they communicate information about the morality of cocoa production.

Acknowledging the agency of objects, however, does not mean that objects determine action. As Latour (2005: 72) notes: "rather, it means that there might exist many metaphysical shades between full causality and sheer inexistence ... [and] things might authorize, allow, afford, encourage, permit, suggest, influence, block, render possible, forbid, and so on." I take the position that resistance, like agency, does not reside in the individual, but is distributed through the assemblage. That is, resistance is a relation, perhaps more temporary than permanent, among agents in the assemblage.

Assemblage theory addresses specific sets of phenomena that articulate shifts associated with globalization (Collier and Ong 2005). This analytic perspective is not oriented to macro-processes of globalization, but to understanding how global forms interact with other elements occupying a common field in what Collier and Ong (2005: 12) describe as "contingent, uneasy, unstable interrelationships," and the objective is to "frame 'the present' in terms of specific trajectories of change" (ibid. p. 15). This article examines how the fine chocolate assemblage began to change with the media publicity about child labor allegations in cocoa production, and restabilized in a consumer practice of buying fine chocolate labeled fair trade. Fair trade products and institutional discourse on fair labor and sustainable farming practices introduced a new dimension to the configuration. The disruption created new 
possibilities. Where sensory enjoyment of fine chocolate once reigned, moral satisfaction moved the assemblage in another direction, namely ethical concern. The case study provides an historical view of fine chocolate and how resistance develops through an assemblage that includes consumers, producers, objects, institutions and discourse.

\section{The global cocoa commodity chain}

The cocoa commodity chain is long and complex, like other commodity chains, and Figure 1 shows the many steps between cocoa growers and consumers. There are continuing changes in the chain. For example, traditionally Ivory Coast, Ghana and other producer countries in West Africa had state marketing boards which controlled purchase of harvested crops, storage in ports, and sale to importers in industrialized countries, but the boards were dismantled as part of IMF structural adjustment programs in the 1990s, except for the one in Ghana which continues to operate (Fold 2002). Now, in most countries, private trading companies handle these functions, as Figure 1 indicates, albeit with increasing vertical integration in the trading/hauling and importer/processor segments.

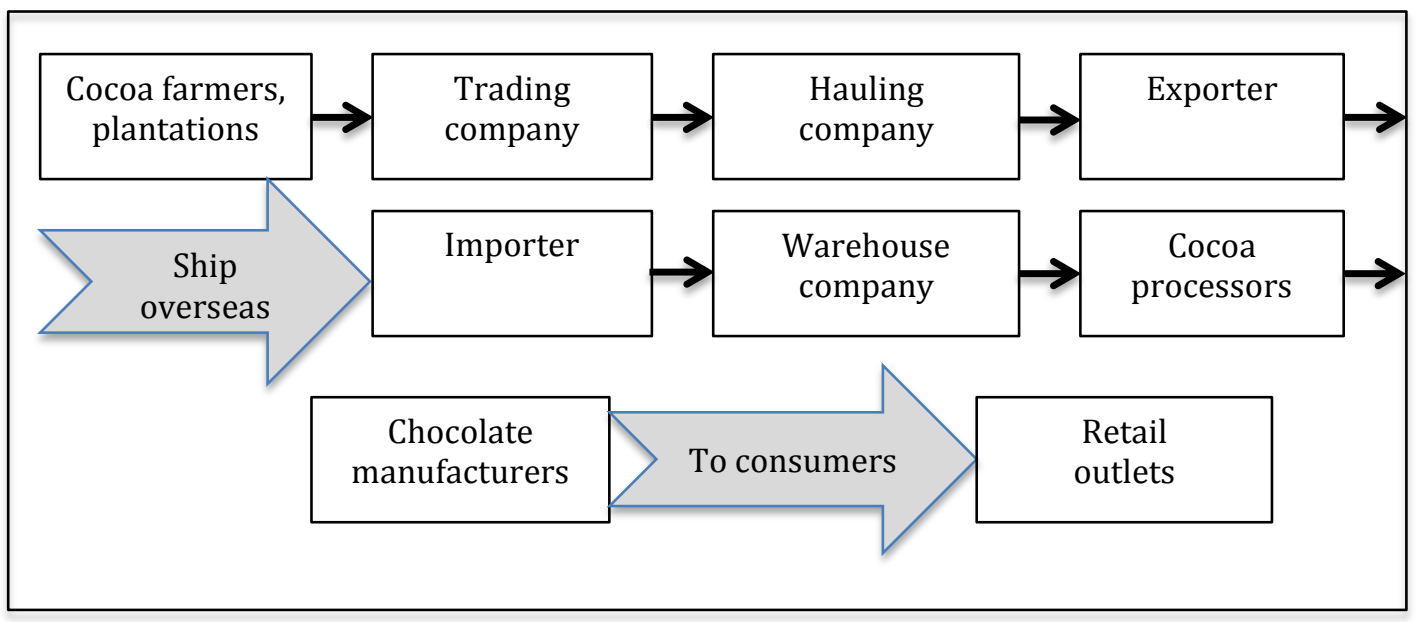

Figure 1: Cocoa commodity chain

For anthropologists, commodity chains provide a way of studying local-global relationships: how local groups are tied into larger networks around the world; what the social relationships and processes are at each step of the chain; where power and profit lie; and whether the system is fair to producers (Goldfrank 2005). In the cocoa commodity chain, cocoa processors hold oligopolistic power (Fold 2002). These are transnational companies like ADM, Cargill and Barry Callebaut, which grind the beans and sell the resulting cocoa mass to large chocolate manufactures such as Cadbury, Hershey, Kraft, Mars and Nestlé, as well as to artisanal manufacturers like Godiva and smaller chocolatiers. Since the dynamics of 
power within the chain are determined in the buyer segments, farmers are price-takers (Fold 2002: 244). A recent trend of situating cocoa grinding facilities in countries of bean origin only increases buyer control.

The critical point about the cocoa commodity chain in relation to my argument is that prior to 2000-2001 media coverage about child labor alleged to exist in West African cocoa production and the subsequent response from government and industry, fine chocolate lovers seemed unaware of steps in the chain before artisanal crafting: that is, of the first two lines in Figure 1. Fine chocolate products were de-territorialized because they were disconnected from cocoa bean production. They were not re-territorialized until awareness about cocoa bean production reached public attention and focus centered on cocoa growers, and on fair labor and sustainable farming practices.

\section{Comparison to coffee}

Coffee sets a useful precedent for the narrative about fine chocolate. Coffee is the world's most traded commodity after oil (Luetchford 2011), and it was the first commodity to become fairly traded (Jaffee 2007). The fair trade coffee industry has expanded greatly. According to the certifying organization Fair Trade USA, annual fair trade coffee imports in the United States have been growing 50 per cent on average for over a decade (Fair Trade USA 2010). The popularity of fair trade coffee developed after the 1989 collapse of the International Coffee Agreement between coffee producing and consuming countries, which had regulated coffee prices for almost 30 years. When the Agreement fell apart, world coffee prices dropped drastically, almost in half, with obvious negative impact on coffee farmers and the economies of coffee-exporting countries. Discourse about the detrimental effects on farmers entered the consumer lexicon through the work of activist groups. Starting in the early 1990s, activists and NGOs promoted fair trade coffees as alternates to major brands (Leutchford 2011). Perhaps more visible in the media was student protest against Starbucks. In 2000, under continuing pressure from students, Starbucks agreed to start selling fair trade certified coffee in all its US stores and in 2005 agreed to increase its fair trade purchases and create new fair trade lines for its college food-service locations (Jaffee 2007).

Similarities between the coffee assemblage and the cocoa assemblage are striking. In both cases, institutional action and discourse about unfairness came to public attention, and products earned fair trade certification. Like chocolate lovers, coffee lovers became enmeshed in a material assemblage including public discourse about unfair conditions of bean production and product labels certifying fair conditions of labor. The significant expansion of the fair trade coffee industry provides ample evidence of resistance to big roasting companies that blend coffees from all over the world for brands such as Folgers, Maxwell House, Chock full 
o'Nuts, and Nescafe.

Reichman (2011) notes that the fair trade label on coffee makes fairness an attribute of the commodity. This is a key point because the material agency of fair trade products in the development of resistance is contingent upon it. Justice and sensual enjoyment are embodied in the product. This case of fine chocolate looks at objects as agents or mediators. As Cochoy (2011: 60) argues in his historical study of the grocery store industry, “... objects are autonomous entities that may shape consumer behavior." In the following narrative of fine chocolate, focus is placed on consumers, producers, objects, institutions and discourse that have abilities and properties to influence purchase decisions.

\section{Defining fine chocolate}

There are many definitions of fine chocolate. A strict definition limits fine chocolate to that made by hand with natural ingredients and premium cocoa beans. For example, the Fine Chocolate Industry Association (FCIA), the only organization oriented to supporting fine chocolate professionals, promotes "the artistry and craftsmanship of the chocolate professional focused on producing superior products made from premium chocolate and natural ingredients" (FCIA 2013). This type of product includes brands such as Amedei, Michel Cluizel, Neuhaus, and Valrhona. A less strict definition includes mass-produced but premium brands like Ghiradelli, Godiva, Lindt, and Perugina. All of these brands are differentiated from large chocolate companies like Cadbury, Hershey, Mars, and Nestlé that mass-produce chocolate candy. This article uses the less strict definition. The most widely recognized brands, including Godiva, fall into the looser definition of fine chocolate. I use the phrase "chocolate lovers" to refer to people who enjoy fine chocolate and are willing to pay the premium price the category commands.

\section{Methodology}

Ethnographic research was conducted at two different points in time, 1989 and 2013. This grounding in time allows juxtaposition of people's perceptions of fine chocolate before and after the pivotal media coverage during 2000-2001. Using research results from these two points in time provides a gauge of how some attitudes and behavior toward fine chocolate have changed.

\section{Initial research}

Initial research was conducted in 1989 for Godiva in five of its main markets: Paris, Brussels, London, Tokyo, and New York. A team of consulting anthropologists used three methods: (1) long in-home 
interviews; (2) in-store videotaping and short interviews with customers; and (3) short interviews with Godiva store managers. At the time, the team of anthropologists was associated with an anthropological market research firm, Holen North America, Inc. in New York City. ${ }^{1}$

We completed a total of 50 in-home interviews with ten people in each of the five markets. Participants were professionally recruited as purchasers of fine chocolate. They reflect a demographic mix by gender, age, marital status and education. The interviews explored everyday life and values, personal history of fine chocolate purchase and consumption, symbols of fine chocolate, general gift giving patterns and how fine chocolate fits into the patterns, and criteria for judging fine chocolate types and brands. Each interview lasted approximately two hours.

To capture customer browsing and purchase behavior in stores and interactions with sales staff, we set up video cameras in a store in each of the five cities where research was carried out. On average, recording lasted seven and a half hours in each city. Intercept interviews were conducted with approximately twenty customers at each site to understand purchase decisions. Interviews with store managers were also conducted to gain background on store operations, sales and customer trends.

Godiva engaged in the 1989 research in order to address competition arising in Japan. Prior to this date, Godiva was the only brand of fine chocolate available on the Japanese market. This led the company to consider repositioning the brand worldwide. At the time, its positioning was based on the prestige of giving. The research was oriented to exploring not only gift giving as a source of new positioning ideas, but also global symbols for eating fine chocolate. Our research focus on actually eating the confections provided an understanding of fine chocolate consumption through an anthropology of the senses (Howes 2005). This is discussed in the next section on fine chocolate and the senses.

\section{Subsequent research}

In 2013 students at the University of Rochester conducted a study of fine chocolate under my supervision. The students were enrolled in an undergraduate course, Local and Global Market Research, which I teach in the Department of Anthropology. Students employed three methods: (1)

\footnotetext{
1 The team of anthropologists consisted of Steve Barnett, Rita Denny, Kevin Dwyer, John Lowe and the author. Steve Barnett, one of the first anthropologists to advocate use of anthropological methods and theories in applied consumer research (Sunderland and Denny 2007), founded the consulting group that became Holen North America, Inc. While I appreciate my teammates' insightful analytic views on the Godiva fieldwork, responsibility for analysis in this narrative on the transformation of fine chocolate remains with the author. I thank Rita Denny for her comments on an earlier draft of the article.
} 
observation of shopping behavior in local fine chocolate shops; (2) oneon-one interviews with 32 fine chocolate consumers; and (3) an online survey of 280 people interested in fine chocolate. We partnered with one of the local fine chocolate shops for this study. ${ }^{2}$

Research participants for the one-on-one interviews were recruited through announcement in the online newsletter of our partner chocolate shop. A mix of people by gender and age responded to the announcement and were interviewed by students, using an interview guide that had been developed in the classroom. The survey questionnaire, also developed in the classroom, was posted on SurveyMonkey for two weeks. People who completed the survey include fellow students, and family and friends of students in the class. Both the interview and survey questions focused on fine chocolate purchase and gift patterns, description of fine chocolate (including a tasting experience during the interviews), desired information about fine chocolate, and comparison of fine chocolate websites.

There were seventeen students in the class. Each wrote a report on observing in a chocolate shop and interviewing fine chocolate consumers. Students then worked in teams to analyze all the data and prepare a PowerPoint presentation on the research results, which was presented to the owner of the local chocolate shop during the last class of the semester.

For the 2013 research, our partner, the owner of a fine chocolate shop, was interested in developing marketing and communication strategies. The study focused on understanding how people relate to fine chocolate brands that come from high quality cocoa beans, grown with fair labor and sustainable farming practices, and hand-crafted with traditional artisanal methods. Based on this study, the role of fair trade chocolate in everyday consumption practices is discussed in a subsequent section.

\section{Juxtaposition of research findings}

Juxtaposing the results of the two research projects permits contextualization of changing attitudes and behavior toward fine chocolate. I suggest that media, government and industry responses to the 2000 BBC documentary alleging that child labor existed in cocoa production created what Dolan (2011) calls an "ethical complex," which influenced consumer beliefs and practices regarding fine chocolate and fair trade. An "ethical complex" refers to knowledge production, interconnected discursive parts that inform consumers. In the case of fine chocolate, the ethical complex includes information in media coverage,

\footnotetext{
2 I am grateful to Nadya Igumensheva, owner of the Cocoa Bean Shoppe in Pittsford, NY, for collaborating on a study of fine chocolate with the students in my class. The students learned a lot from working on the project with her.
} 
discourse from government and industry, and communications from fair trade marketing. Dolan (2011: 43) notes that people's decisions to purchase fair trade are not based on direct observation of labor and farming situations. The knowledge deficit is filled by an ethical complex that "mediates the world of producers and the ethical dispositions of consumers."

Juxtaposing research results from the two different points in time indicates how resistance developed in the fine chocolate market. Prior to the 2000-2001 publicity, fine chocolate was deterritorialized, in the sense that it was perceived to be a craft made in France and Belgium. This perception referred to chocolatiers crafting the finished product, not to cocoa farmers producing beans. Following the publicity, fine chocolate assumed a moral dimension. Fair trade labels on fine chocolate reterritorialized the finished product by attaching cocoa beans to specific geographies and fair conditions of production. The two sets of data from the Godiva research and the student research offer a vantage point from which to view the development of resistance and support of fine chocolate labeled fair trade.

In the next section, the ethnographic narrative starts by tracing connections between chocolate lovers and fine chocolate products, and by showing how the products provide deep sensual enjoyment and rich symbolic meaning for consumers. The narrative continues with a discussion of the deterritorialization and reterritorialization of fine chocolate. Finally, the narrative discusses how media, government, and industry generated an ethical complex that introduced a moral element into the fine chocolate assemblage.

\section{Fine chocolate and the senses}

At the time of the 1989 research, we discovered from our research participants that enjoyment of fine chocolate comes through senses that are culturally mediated. People discern the merits of fine chocolate by sensory evaluation, and the sensual criteria for judging whether particular confections are good or not vary cross-culturally. Different aspects of the senses are key in assessing fine chocolate in Japan, Europe, and the United States. The variation, described below, begins the narrative of fine chocolate as a deterritorialized, class based, luxury product.

\section{Japan}

In 1989 the most frequent occasion for giving fine chocolate in Japan was Valentine's Day. Women gave chocolate to men in superior positions (for example, to an employer or a child's teacher). Men competed over who received the most boxes with the kind of joking behavior that 
anthropologists have long noted in other societies (Radcliff-Brown 1940). While the gift giving reifies the social hierarchy, there is a paradox in that men claimed not to eat the chocolate they received. However, upon interviewing men and women in their homes, we found that fine chocolate with coffee and liquor often constituted a dessert shared between husband and wife at home. Such reluctance to admit chocolate consumption was a social mask. It hid expression of inner desire and private behavior occurring in the home.

For our Japanese respondents, fine chocolate connoted high social class, because it came from Europe and reflected world travel and sophistication. It was often brought as a gift from abroad as a symbol of Western refinement. Chocolate was introduced to Japan during World War II when American GIs gave their candy bars to Japanese children. The first local chocolate produced in Japan was a mass produced brand, and Japan did not make premium chocolate at the time of the 1989 research. Traditional Japanese sweets were (and still are) salty, made with azuki beans, chestnuts, and vegetables flavored by soy sauce or seaweed.

When our Japanese respondents talked about the experience of eating fine chocolate, they focused on the sense of smell. Aroma was the most important criteria for judging quality. According to respondents, an enticing smell emanated from chocolate that was handmade, and therefore natural or not machine-made. Handmade production draws on the meaning of artisanship in traditional Japanese crafts. Brian Moeran's (1997) ethnography of folk craft potters in southern Japan shows that traditional methods of production, which involve making things with natural ingredients and cooperative labor, are important to the Japanese. In fact, many of Japan's traditional crafts-paper making, textiles, lacquer, and metal work, as well as pottery-are officially recognized and protected by the 1951 Law for the Protection of Cultural Properties. The Law covers tangible properties like buildings and objects, as well as intangible properties such as craft techniques, all of which are connected to different parts of the country and various time periods. Overall the Law speaks to artisanship and the heritage of the Japanese people.

\section{Europe}

In Europe as well as the United States, fine chocolate was purchased as a gift on formal and informal occasions and for self-consumption. Despite differences in consumption practices of people in the European cities where the 1989 research was conducted (Brussels, Paris, London), there were two distinct meanings of fine chocolate in Europe. One meaning was health-derived from the practice of eating chocolate with breakfast and the belief that chocolate adds an additional healthy component to the meal; the other was extended family conviviality. At family dinners with extended family members, a box of fine chocolate was often placed on the table, to be shared at the close of the meal. For relatives present, passing 
around the box and eating the chocolate symbolized family togetherness, fun, and caring.

Our European participants discussed the experience of eating fine chocolate in terms of the sense of taste. Flavor intensity topped their list of criteria for judging quality. Good taste was thought to come from pure and natural ingredients. The purer the ingredients, the more the chocolate was said to have a "rich" and "authentic" taste. Experience of such an intense chocolate flavor referred to meanings of aristocracy, "pure blood," and something being genuine and untainted by impurity. The purity of taste in fine chocolate seemed "beyond the commoner, fit for a king". In a study of British royal symbols and rituals, Hayden (1987) discusses practices concerning the purity of royal and aristocratic blood. As she points out, having aristocratic blood is something that needs to be demonstrated. Relations of blood must be traceable throughout the whole group of aristocrats, so that blood and purity are symbolically combined. Interestingly, there is difference between aristocratic and royal blood. Royalty is either ascribed by birth, or achieved by marriage to a royal person. However, Hayden (1987:41) says, the popular assumption that "once royal always royal" is not true.

"Royal blood is a volatile and evanescent substance that vaporizes by the third generation, and with it dissipates an individual's right to a princely title. After the third generation in the male line (sooner in the female line), the blood royal stabilizes as the merely blue; erstwhile royalty blends imperceptibly with the aristocracy."

Movement between royalty and aristocracy can occur depending on whether a person's blood is "royal" or "merely blue." As Hayden later explains (1987: 109), new members of royalty are recruited from the ranks of the aristocracy and those sloughed off are returned to it. These social intricacies in defining the top echelons of society indicate the importance of the idea of purity in the UK, and perhaps in other European countries such as Belgium and France with similar roots in monarchy. Even where monarchy no longer exists, the idioms of power continue to frame "the inherent sacredness of central authority" (Geertz 1983:146). Concern for the idiom of purity seemed to be refracted in the criteria for judging the quality of fine chocolate among our research participants. For them, it was pure ingredients that yielded good taste.

\section{United States}

Compared to the social context of consumption in Japan and Europe, fine chocolate in the United States was a personal experience. A box of chocolates was not typically shared among household members, but hoarded and eaten privately, especially by women, almost as if it were something illicit. That women are the main consumers of chocolate has 
been recognized since the industry emerged in the US during the early 1900s (Lopez 2002).

For our female respondents, fine chocolate was a feminine indulgence and gateway to natural sensuality. It brought memories of childhood, and of how mothers would give inexpensive chocolate candies as rewards and signs of caring. Fine chocolate also awakened adult sensual thoughts and feelings of body enjoyment. So, fine chocolate had the polarizing effects of providing transportation to the innocence of childhood, on the one hand, and of the sexuality of adulthood, on the other. The sensation of craving fine chocolate came from these symbolic associations, as well as desire for the remembered taste and texture of the product.

Our US respondents talked about the experience of eating fine chocolate in relation to the sense of taste-albeit in a nuanced way that differed from that of our European respondents. While Europeans spoke of the intense flavor of chocolate made with pure ingredients, the main criterion for evaluating fine chocolate in the United States implied texture and the crispness that came from freshness. This referred to shelf life, and to the belief that the longer a product stayed on the shelf the less fresh and stale it became. When stale, chocolate was thought to lose its natural crispness and become too soft. Freshness was experienced through sound by hearing a crunch when biting into a piece of chocolate, and through touch as the mouth felt the hard edges of the chocolate, and then the silky feel of it melting on the tongue.

This concern with shelf life and the freshness of fine chocolate is part of a larger consumer interest in food quality, safety and date marking (Man and Jones 2000). Responding to consumer calls for food quality and safety, the US Department of Agriculture and the Federal Drug Administration have been long active in regulating the date marking of foods, beverages, pharmaceutical drugs, chemicals, and many other perishable items. Manufacturers and retailers participate in date marking efforts including the "use by" and "best by" codes familiar to shoppers. In industry terms, shelf life refers to food quality and expiration date relating to food safety. Chocolate has a relatively stable shelf life due to the properties of cocoa (high fat content and low moisture content), but product degradation can occur if proper manufacturing and storage procedures are not followed (Martin 2000). For example, as Martin (ibid. p. 171) explains, the chocolate can lose its snap and become soft during the enrobing part of the manufacturing process, if the enrobed centers cool too slowly. Our research participants said that they judged the quality of fine chocolate through the sensual experience of the product's texture. When it was crispy, they knew it was fresh and merited the claim of quality. 


\section{Inner and outer orientation to luxury products}

Thus, in relying on the senses to recognize fine chocolate, our research participants focused on the inner orientation of luxury and the experience of indulgence (Yeoman 2011). Respondents appreciated fine chocolate as "natural," a global symbolic category with a cluster of sensual meanings including aroma, taste and texture. However, the outer orientation of luxury was also important to chocolate lovers. Giving and consuming fine chocolate-literally the taste of distinction (Bourdieu 1984)-communicated high-class status. This status was based on the perception that fine chocolate came from West European countries (Belgium, France, England). The perception deterritorialized fine chocolate because cocoa beans, the main ingredient in fine chocolate, do not come from Europe. Growing beans and crafting confections occur at different points in the cocoa commodity chain.

\section{Fine chocolate as haute cuisine from Europe}

The ability of fine chocolate to connote high social class emerges from its perceived provenance as European haute cuisine. At the time of the 1989 research, our research participants considered Godiva and other brands of fine chocolate to be from Belgium and France. These brands were regarded as the finest in the world and fittingly priced as luxury items. Godiva's gold ballotin box, still in use today, symbolized prestige and high-class status to our respondents.

Mintz (1996) makes a distinction between cuisine and haute cuisine that is useful in understanding the perceived provenance of fine chocolate as haute cuisine. According to his definition, cuisine comes from local and regional food sources and a community of users who share recipes and favorite dishes, while haute cuisine transcends geography. It is classbased and relies on sophisticated cooks and knowledgeable consumers. As Terrio (2000) notes in her study of French chocolatiers, this distinction between the categories of cuisine and haute cuisine fits the difference between mass-produced and premium chocolate: "by conforming to this paradigm, chocolate haute cuisine spurns the chocolate of the masses" (2000: 58). This is because fine chocolate depends on higher quality cocoa beans, a higher percentage of cocoa solids, and less sugar than is used in mass produced chocolate candy. As we have seen, chocolate lovers recognize the haute cuisine quality of fine chocolate through sensory perception.

There is also cognitive perception in recognizing fine chocolate as European haute cuisine. Our 1989 respondents assumed that fine chocolate came from European countries like Belgium and France. In fact, US and Japanese respondents did not realize that Godiva was an American-owned brand. Most thought Godiva had retained its brand roots as a Belgian company. However, Godiva was actually owned by the 
Campbell Soup Company at the time of the 1989 research. Acquired during the heyday of corporate diversification in the US, Godiva was a Campbell's brand for 40 years, from 1967 to 2008, until purchase by its present owner, Turkish holding company Yildiz Holding. Similarly, even those European respondents who realized Godiva was a brand under US ownership, considered Godiva to be European because it continued to make its chocolates in Belgium, even though it was owned by a US company.

Thus, it was the implicit knowledge that fine chocolate originated in Europe that deterritorialized the product, because Europe constituted only a midpoint in the cocoa commodity chain. Looking at the whole chain, however, we can say that fine chocolate originates from cocoa beans, which grow only in tropical areas outside Europe. Based on the perception of fine chocolate as European haute cuisine, however, fine chocolate was a deterritorialized product traveling around the world, circulating among higher social classes. It has been available, for instance, at duty free shops in international airports for decades.

Attributing the origins of fine chocolate to Europe reflects a partial view of chocolate and its history. True, the confection was initially crafted in Europe. Spanish explorer Hernan Cortez is credited with bringing cocoa beans from Mexico to Spain in 1528, and the secret of how to make a chocolate product from the bean remained with the Spanish court for almost 100 years, before eventually spreading to other European countries through political marriages among royal families (Lopez 2002). But cocoa was used to make a beverage, a bitter one, in Europe as it was in Mexico, until the cocoa press was invented in 1828 by the Dutch chemist, C. van Houten, and the confection we know as chocolate could be made. Thus, to consider fine chocolate European haute cuisine only tells the story of chocolate from a midpoint in the cocoa commodity chain. It leaves out the process of growing beans in the tropical regions of Africa, Indonesia, Latin America, and the Caribbean. The beans are roasted and ground before chocolatiers make the finished product. Transformation of fine chocolate from a deterritorialized, class based, luxury product into a reterritorialized, local, and fair trade one takes into account the whole cocoa commodity chain starting with production of beans. The narrative of fine chocolate now turns to the social processes that shaped the transformation of the product into a morally compelling one.

\section{Completing the cocoa commodity chain}

Consumer concern with cocoa production is related to the spread of local food movements and the fair trade movement in the late twentieth century. Local food movements, starting with Italy's Slow Food movement in 1986, have raised concern over where food comes from and how it is grown. The globalization of the food supply has drawn awareness to the authenticity of traditional foods, such as heirloom corn and tomatoes. 
Recent local food movements have emphasized a direct consumer relationship with producers, through farmers markets and community supported agriculture. Overall, local food movements have fostered local, sustainable, and just food production-in contrast to the globalized industrial processed food system (Counihan and Van Esterik 2013).

Also connected to consumer concern with cocoa production is the fair trade movement. Cocoa has played a significant role in the development of fair trade in the late twentieth century. Fair trade chocolate has been a rapidly expanding market in Europe and North America since the first chocolate brand (Green and Black's) was awarded the fair trade mark in 1994 (Berlan 2011). The fair trade movement has focused public attention on the source of cocoa beans: where they come from, and how they are grown. One effect of this attention is tying beans to specific countries and even specific farms. This more transparent connection of confection to bean is used in marketing efforts to highlight the quality of beans from a specific place. In the marketplace, chocolate lovers are presented with brands of fine chocolate made from single origin: for example, the Tocoti brand made in Rochester, New York, with beans from Venezuela, Belize, Peru, or the Dominican Republic. Chocolatiers promise superior taste from single origin beans. Fine chocolate is reterritorialized because the transparency links brands to specific geographies and places of bean production.

Cocoa is a precious agricultural commodity, not only because chocolate confections give people enjoyment, but also because of sustainability issues. Beans grow only in tropical areas ten degrees above and below the equator, and recent environmental damage in these areas may severely limit availability of cocoa on commodity markets in the future (Lopez 2002). That industry has not developed an artificial substitute for the bean only makes cocoa more precious. Some chocolatiers have developed relationships with specific cocoa farmers, in order to respect worker rights and the environment: for example, the Taza Chocolate brand made in Somerville, Massachusetts, has direct longterm buying relationships with small farmers working in cooperatives in the Dominican Republic, Bolivia, and Belize. Such relationships also secure exclusive access to a diminishing and potentially lucrative market.

We discovered from our research participants in the 2013 study of fine chocolate practices that there is consumer interest in fair trade chocolate, and concern over labor and farming practices in cocoa production. One of the research participants I interviewed said that he remembers the 2000-2001 media coverage alleging use of child labor in West African cocoa farming, and that it changed his feelings about buying fine chocolate. Since that time he has bought fair trade chocolate because it provides assurance that the beans are grown without abusing children or adults. Another research participant interviewed by one of the students said: "I didn't like the idea that anyone working to make a treat 
as delicious as chocolate could be taken advantage of." Yet another participant interviewed by a student commented: "I get such a positive feeling, a rush, when eating fine chocolate that I feel better knowing that those who made this magical concoction were treated and paid fairly." Referring to concern about sustainability as well as labor, a woman interviewed by a student added that she buys fair trade chocolate because it's better for people and the environment.

Underlying the purchase of fair trade chocolate is an ethical concern. A participant in the 2013 research said: "it's a matter of ethics. I want to be responsible with my money and support things I see ethically eye-to-eye." As James Carrier notes, because ethical consumers inject social values into the economic realm, they use the economy as a signaling system: that is, "...when people buy one thing rather than another, their purchase signals their preference, a signal that passes up the chain from shop to wholesaler to manufacturer" (Carrier 2012: 6). Of course, not all participants in the 2013 research were committed to buying fair trade chocolate. The ethical complex deriving from institutional response to allegations of child labor in West African cocoa farming created some ambiguity. There were conflicting claims, so the actual production situation wasn't necessarily clear to people. Consequently, the ethical complex-consisting of information from media, government and industry following the BBC 2000 documentary-may leave people unsure about how to interpret contradictory statements about labor and farming practices in cocoa production. In order to understand how resistance was created through the ethical complex, the next section discusses institutional discourse and action, development of the fair trade chocolate market, and stabilization of a fine chocolate assemblage.

\section{Ethical complex and institutional context}

Several US institutions have generated public discourse on unfair labor practices, and on unsustainable farming practices reported in cocoa production. Media, government and industry have addressed these nefarious practices to generate public awareness and try to correct them. Public communications from the institutions constitute an ethical complex on fair labor and just cocoa production. This information has politicized morality and added a new dimension to the fine chocolate assemblage. Yet, as we look at the moral discourse, it will become apparent why it does not fully clarify the pragmatics of cocoa growing, and in fact leaves chocolate lovers in an ethical quandary. As a result, the ethical complex motivates and inhibits purchase of fine chocolate labeled fair trade.

\section{Media}

Widespread media coverage following alleged use of child labor in West 
African cocoa farming focused public attention on production of the beans. Two media stories were particularly instrumental in provoking concern about children in cocoa production: one was the BBC documentary, initially aired in 2000 , claiming that children were being taken by traffickers to cocoa farms in the Ivory Coast and treated like slaves; the other story reported that a ship, named the Etireno, found in the Gulf of Guinea in 2001, was carrying almost 250 child slaves headed to work on West African cocoa plantations (Berlan 2009). This publicity catalyzed government action, industry response, and consumer resistance.

However, the media may have overstated facts on use of children in cocoa farming, thereby sensationalizing the reporting. The majority of cocoa globally is produced in keeping with international labor standards (Berlan 2012), and it would not be correct to characterize the whole cocoa industry as abusive. While the publicity spoke of forced child labor on West African cocoa plantations, 90 per cent of cocoa is grown on family farms in West Africa (Berlan 2011). In addition, based on ethnographic fieldwork in Ghana, Berlan (2009: 143) found that many of the media reports were contentious: "As a crop, cocoa provides a livelihood for millions of farmers and their families, and the majority of children who work on cocoa farms freely, voluntarily and in a family context, at least in Ghana (currently the world's second largest producer of cocoa), were largely overlooked in these accounts" (2009:143). Even The Economist (2001: 3), while not discounting problems with child slavery and trafficking for unpaid labor and sexual exploitation in West Africa, said of the Etireno incident that "it turned out to be largely a false alarm." According to this report, when the boat returned to port, it contained only a few children, but 139 adult passengers, most of whom were desperately seeking jobs in West Africa.

The media discourse, whether sensationalizing and misrepresenting West African cocoa production, or more accurately capturing the truth of its production, began to re-define the space between producers and consumers. The social process of covering the news brought change to the definition of the cocoa bean as commodity, and to fine chocolate as confection. Morality infiltrated the fine chocolate assemblage. Informed chocolate lovers could engage in acts of resistance by buying fine chocolate labeled fair trade.

\section{Government}

The US government also participated in the evolving ethical complex about cocoa production in West Africa. Responding to media reports about child slavery and trafficking, the US Congress negotiated the Cocoa Protocol with industry. Formally known as the Harkin-Engel Protocol (in recognition of Senator Tom Harkin and Representative Eliot Engel who negotiated it), the Protocol is an international agreement signed in 2001 
by all the world's major mass-producing chocolate companies-including Hershey, Mars, Nestlé, and ADM-under the auspices of the Chocolate Manufacturers Association and the World Cocoa Foundation. The Protocol aims to end the worst forms of child labor under the International Labor Organization's Convention 182, and forced labor under Convention 29, and is focused on ending child labor in the two largest cocoa producing countries, Ivory Coast and Ghana.

Effectiveness of the Protocol remains contested to this day (Hughlett and Spencer 2013). The chocolate industry claims that it has addressed five of the Protocol's six articles. The sixth article-arguably the most difficult and costly to implement-calls for industry-wide standards for public certification that cocoa has been grown without any of the worst forms of child labor. Presumably this would entail a label on finished products that consumers could see. However, the Payson Center for International Development at Tulane University, which the US government contracted to oversee industry efforts related to the Cocoa Protocol, found that, as of 2011, the cocoa industry had not fully completed any of the six articles (Payson Center 2011). These contradictory statements from industry and its overseer leave an ambiguous record for concerned citizens and chocolate lovers. In addition, accountability issues concerning use of forced child labor arise from passing the buck up and down the commodity chain: farmers blame cocoa prices; middlemen deny forced child labor; West African governments blame foreign companies operating within their borders; cocoa suppliers wave responsibility since they don't control farmers; and chocolate companies claim they rely on their suppliers to provide cocoa grown without forced child labor (Raghavan and Chatterjee 2001).

The extent of the Protocol's effectiveness raises the larger issue of governance in global commodity chains. Economic sociologists examining global value chains underscore the role of powerful companies, or "lead firms," in a segmented system of global economic governance (Gibbon, Bair and Ponte 2008), and point out the importance of regulation in achieving desired economic outcomes. Based on their analysis, international organizations such as the World Trade Organization, G-8, and international financial institutions influence economic outcomes-not as a result of pressure by lead firms to obtain rules favorable to their interests, but through the impact of regulation on how lead firms organize international production networks (Gibbon et al. 2008: 316). In relation to lead firms who signed the Cocoa Protocol, adherence may be inspired by public exposure, fear of criticism, loss of sales, profit reductions, and concern to do the right thing. However, the force of regulation is absent. The voluntary and non-binding Protocol does not have the potency of government regulation or international law.

Although the Cocoa Protocol has not achieved full compliance, government discourse on cocoa production has become part of the fine 
chocolate assemblage. The discourse raises citizen awareness of human rights issues in cocoa farming. The US Congress has continued its Cocoa Protocol activities through Joint Statements in 2005 and 2008, which extend the government's commitment to address forced child labor problems, and through the Joint Declaration in 2010, which aims to reduce by 70 per cent the worst forms of forced child labor by 2020. Yet, because the Cocoa Protocol provides limited accountability (since it is a voluntary, non-binding agreement), consumers lack ways of learning whether specific fine chocolate companies and brands rely on cocoa grown without forced child labor. Chocolate lovers concerned with these ethical issues must rely on the word of chocolatiers whom they know and trust. An exception to the conundrum is fine chocolate that is labeled fair trade.

Industry

Industry and the Fairtrade Labelling Organizations International (FLO), which is the worldwide fair trade standard setting and certification organization, have contributed to the ethical complex in terms of information on just cocoa production. The fair trade movement went from marginal to mainstream in the closing decades of the twentieth century, with a growing number of brands in the marketplace and increasing pressure on manufacturers to make supply chains ethical (Berlan 2008). Consumer interest in fair trade chocolate has been rising at a greater rate than the rest of the chocolate market. Between 1996 and 2006 , the annual average growth of fair trade-labeled cocoa products was 23 per cent-in contrast to the two to three per cent growth in the conventional chocolate market (Barrientos 2008, cited in Berlan 2011: 123). Moral discourse on fair trade chocolate has thus not only entered the consumer lexicon, but also motivates purchase. Chocolate brands that gain FLO certification contain the momentum of resistance in the fine chocolate assemblage. The fair trade label informs people that their concerns for farmers and their lives-as well as for non-abusive labor and for sustainable farming methods that protect the environment-are being addressed.

Although fair trade labeled cocoa is a rapidly expanding market, it constitutes only one percent of global cocoa production (Berlan 2011). Two key factors constrain resistance in relation to purchase of fine chocolate labeled fair trade. First, not all fine chocolate brands have acquired fair trade certification. Only 4 of the 17 brands of fine chocolate listed on the 2013 research survey are fair trade certified (Equal Exchange and Theo from the US and Divine Chocolate and Green \& Black's from the UK). Second, these fair trade brands are not well known. Each had only $8 \%$ or less name recognition (Table 1). Yet awareness of just production has entered consumer consciousness, and there is a difference between being aware of fair trade chocolate and recognizing particular 
brand names. Aware of just and unjust production, chocolate lovers often trust claims from individual chocolatiers that the fine chocolate they sell is made from single origin cocoa beans under fair labor and farming conditions even though it is not certified and labeled fair trade.

The moral discourse on fair trade chocolate has force as an agent that is reflected in consumer thinking. Our 2013 survey respondents show strong albeit not overwhelming interest in fair trade chocolate. In response to the survey question, how you would define fine chocolate, fair trade is one of the elements that come to mind; other elements that come to mind relate to taste and luxury status (Table 2). In addition, desire to learn about fair trade chocolate was significant but less high than learning about taste aspects of fine chocolate (Table 3). Based on our 2013 interviews, people often place taste, sensual enjoyment and attachment to favorite brands ahead of other purchase criteria. Nonetheless, the data indicate that sensory enjoyment of fine chocolate has become entangled with social, economic and political processes that have added a moral dimension to its production, marketing and consumption. In the United States, consumer criteria for judging fine chocolate now include not only taste and texture but also the morality of production. The ethical complex generated by media, government and industry interjected the cultural value of justice. The continuing rapid rise of the fair trade chocolate market indicates a correspondence in the fine chocolate assemblage of consumers, producers, institutions and discourse on justness, and fine chocolate products labeled fair trade.

\section{Conclusions}

This article has identified a trajectory of change in the fine chocolate assemblage. Juxtaposing ethnographic research conducted in 1989 and 2013 suggests that fine chocolate has been transformed from a product enjoyed for its sensuality to a product also capable of generating moral satisfaction. At the time of the earlier research, fine chocolate was evaluated on sensual meanings of aroma, taste, and texture, and associated symbolic meanings nuanced by place (Japan, Europe, and the US). By the time of the later research, concern for justice and sustainability in cocoa production had crossed the radar screen of US chocolate lovers and influenced purchase of fine chocolate products sold under the fair trade label.

Ethnographic research at the two different points in time reveals different meanings in the social life of things, and resistance figures in the cultural biography of fine chocolate (Kopytoff 1986). As a result of the social, economic, and political processes described here, consumers can engage in acts of resistance to unfair labor and unsustainable farming practices by buying fine chocolate labeled fair trade. Fine chocolate producers also seem to recognize the moral force in the fine chocolate assemblage. Marketing efforts speak about direct buying relationships 
with farmers, and the superior taste of chocolate made from a known single origin. Such representations of fine chocolate reflect coconstruction, the new dominant logic of marketing (Cheetham and McEachern 2012; Oliviera 2012), which focuses on producers as well as consumers. So the political morality of cocoa production finds expression in marketplace ideologies and strategies, and in consumer decisionmaking.

I have argued that an ethical complex on fair labor and sustainability initiated the trajectory of change. This new element in the fine chocolate assemblage came into existence after release of the 2000 BBC documentary about child labor allegations in West African cocoa production. Subsequent media publicity, the discourse related to the Cocoa Protocol between the US government and the chocolate industry, and fair trade marketing communications generated an ethical complex related to growing cocoa. This set of ideas about fair labor and sustainable farming practices came to public attention, and redefined the space between production and consumption. Fine chocolate shifted away from the category of European haute cuisine, crafted by chocolatiers in countries like France and Belgium-a midpoint in the commodity chain and deterritorialized fine chocolate-and became tied, instead, to specific places of cocoa bean production in tropical regions of the world. The shift, taking the whole commodity chain into consideration, reterritorialized fine chocolate.

The narrative of fine chocolate considers resistance a form of agency that is distributed in an assemblage. In situating resistance within the fine chocolate assemblage, the analysis goes beyond notions of agency residing in the individual. As Latour writes, "... the most powerful insight of social sciences is that other agencies over which we have no control make us do things" (2005: 50). This notion of agency does not privilege humans as autonomous, individual decision-makers (Maurer, Nelms and Rea 2013). Rather, inanimate things-as well as non-human animate ones such as pets-may have capacity for action (McCabe 2014). The fine chocolate assemblage, which includes consumers, producers, objects, institutions and discourse, shows how consumers are enmeshed in material assemblages that have force or momentum. The materiality of things is thus a constitutive part of agency (Cochoy 2011).

Fine chocolate products with fair trade labels attune consumers to the pragmatics of cocoa production. As Cochoy (2011: 80) puts it: "social meaning and social agency are thus both distributed between people and things." The fine chocolate narrative suggests that resistance develops as a relation among components that come together in an assemblage. This construction broadens earlier notions of agency positing opposition between agency and structure, where the actions of individuals are taken in contradistinction to established structures (Mills 2013). Assemblages are composed of dynamic relations, always in a process of becoming, and 
dependent on categories of human thought and design (DeLanda 2006). This broader conceptualization of agency and resistance distributed within assemblages seems more helpful in understanding consumer practices of advanced capitalism.

Anthropologists concerned with the contribution of fair trade to social justice point out that the fair trade system improves the lives of farmers and families in coffee producing communities, but that it does not address systemic inequalities (Jaffee 2007; Reichman 2011). Fair trade purchases fall at one end of consumer activism. According to political scientist Eleftheria Lekakis (2013), coffee activism includes a range of activities-from single consumer preference to fully committed engagement in protesting and lobbying, as well as boycotting unethical coffee trade. Lekakis calls fair trade coffee purchases "politics in the pocket," or opportunities for civic engagement by citizens through consumption practices in everyday life. According to this framework of levels of activism, buying fine chocolate labeled fair trade involves individual acts of resistance that take place inside, not outside, the marketplace. The resistance has taken shape within an assemblage that changed relations between producers and consumers at the turn of the $21^{\text {st }}$ century. 
Table 1

Which of the following brands are you familiar with? (check all that apply)

\begin{tabular}{|l|c|}
\hline Divine Chocolate & $6 \%$ \\
\hline Equal Exchange & $8 \%$ \\
\hline Ferrero Rocher & $75 \%$ \\
\hline Ghiradelli & $89 \%$ \\
\hline Godiva & $96 \%$ \\
\hline Green \& Black's & $8 \%$ \\
\hline Guylian & $9 \%$ \\
\hline Lindt & $94 \%$ \\
\hline Michel Cluizel & $1 \%$ \\
\hline Perugina & $5 \%$ \\
\hline Royce & $5 \%$ \\
\hline See's & $31 \%$ \\
\hline Taza & $10 \%$ \\
\hline Theo & $1 \%$ \\
\hline Thortons & $2 \%$ \\
\hline Tocoti & $5 \%$ \\
\hline Valrhona & $6 \%$ \\
\hline None of the above & $1 \%$ \\
\hline
\end{tabular}

\begin{tabular}{|l|c|}
\hline \multicolumn{2}{|c|}{$\begin{array}{c}\text { Table 2 } \\
\text { How would you define fine chocolate? } \\
\text { (check all that apply) }\end{array}$} \\
\hline Expensive & $50 \%$ \\
\hline All natural & $24 \%$ \\
\hline Organic & $16 \%$ \\
\hline Fair trade & $15 \%$ \\
\hline Upscale & $41 \%$ \\
\hline Rich taste & $93 \%$ \\
\hline Bold flavor & $54 \%$ \\
\hline Other & $4 \%$ \\
\hline
\end{tabular}

\section{Table 3}

What information about fine chocolate would you like to know? (check all that apply)

\begin{tabular}{|l|l|}
\hline Ingredients & $61 \%$ \\
\hline How it is made, how the taste is created & $61 \%$ \\
\hline The percentage of cocoa & $59 \%$ \\
\hline Where cocoa beans are grown and harvested & $34 \%$ \\
\hline Processing and production & $26 \%$ \\
\hline Fair trade & $40 \%$ \\
\hline
\end{tabular}




\section{References}

Ahearn, L. M. 2001 "Language and agency." Annual Review of Anthropology 30: 109-37.

Berlan, A. 2008 "Making or marketing a difference? An anthropological examination of the marketing of fair trade cocoa from Ghana." In G. De Neve, P. Luetchford, J. Pratt and D. C. Wood (eds.), Hidden hands in the market: ethnographies of fair trade, ethical consumption, and corporate social responsibility. Research in Economic Anthropology 28: 171-94. Bingley: Emerald Group.

Berlan, A. 2009 “Child labour and cocoa: whose voices prevail?' In M. Leonard (ed.), Child work in the twenty-first century: dilemmas and challenges. The International Journal of Sociology and Social Policy 29: 141-51.

Berlan, A. 2011 “Case studies: cocoa." In M. Warrier (ed.), The politics of fair trade: a survey, pp. 123-29. London: Routledge.

Berlan, A. 2012 "Good chocolate? An examination of ethical consumption in cocoa." In J. G. Carrier and P. G. Luetchford (eds.), Ethical consumption: social value and economic practice, pp. 43-59. New York: Berghahn Books.

Bourdieu, P. 1984 Distinction: a social critique of the judgement of taste. R. Nice (trans.). Cambridge: Harvard University Press.

Carrier, J. G. 2012 "Introduction." In J. G. Carrier and P. G. Luetchford (eds.), Ethical consumption: social value and economic practice, pp. 1-36. New York: Berghahn Books.

Cheetham, F. and M. G. McEachern 2012 “Extending Holt's consuming typology to encompass subject-subject relations in consumption: lessons from pet ownership." Consumption, Markets and Culture 16: 91-115.

Cochoy, F. 2011 “'Market-things inside:' insights from Progressive Grocer (United States, 1929-1959)." In D. Zwick and J. Cayla (eds.), Inside marketing: practices, ideologies, devices, pp. 58-84. Oxford: Oxford University Press.

Collier S. J. and A. Ong 2005 "Global assemblages, anthropological problems." In A. Ong and S. J. Collier (eds.), Global assemblages: technology, politics, and ethics as anthropological problems, pp. 3-21. Oxford: Blackwell.

Counihan, C. and P. Van Esterik 2013 "Why food? Why culture? Why now? Introduction to the third edition." In C. Counihan and P. VanEsterik (eds.), Food and culture: a reader, pp. 1-15. New York: Routledge.

DeLanda, M. 2006 A new philosophy of society: assemblage theory and social complexity. London: Bloomsbury.

Dolan, C. S. 2011 “Branding morality: the case of fairtrade." In M. Warrier 
(ed.), The politics of fair trade: a survey, pp. 37-52. London: Routledge.

Fair Trade USA 2010 "Impact report."

www.fairtradeusa.org/sites/default/files/Coffee Impact Report-2.pdf

Accessed 2 April 2014.

Fine Chocolate Industry Association. 2013 "Share our passion."

www.finechocolateindustry.org Accessed 8 April 2013.

Fold, N. 2002 "Lead firms and competition in 'bi-polar' commodity chains: grinders and branders in the global cocoa-chocolate industry." Journal of Agrarian Change 2 (2): 228-47.

Geertz, C. 1983 "Centers, kings, and charisma: reflections on the symbolics of power." Local knowledge: further essays in interpretive anthropology, pp. 121-46. New York: Basic Books.

Gibbon, P., J. Bair and S. Ponte 2008 "Governing global value chains: an introduction." Economy and Society 37 (3): 315-38.

Goldfrank, W. L. 2005 "Fresh demand: the consumption of Chilean produce in the United States." In J. L. Watson and M. L. Caldwell (eds.), The cultural politics of food and eating: a reader, pp. 42-53. Oxford: Blackwell.

Hayden, I. 1987 Symbol and privilege: the ritual context of British Royalty. Tucson: University of Arizona Press.

Howes, D. 2005 “Introduction: empires of the senses." In D. Howes (ed.), Empire of the senses: the sensual culture reader, pp. 1-17. Oxford: Berg.

Hughlett, M. and J. Spencer 2013 "Child labor abuses persist on Africa's cocoa farms." www.kitsapun.com, posted June 11, 2013. Accessed 16 January 2014.

Inda, J. X. and R. Rosaldo 2002 "Introduction: a world in motion." In J. X. Inda and R. Rosaldo (eds.), The anthropology of globalization: a reader, pp. 1-34.

Izberk-Bilgin, E. 2010 "An interdisciplinary review of resistance to consumption, some marketing interpretations, and future research suggestions." Consumption, Markets and Culture 13 (3): 299-323.

Jaffee, D. 2007 Brewing justice: fair trade coffee, sustainability, and survival. Berkeley: University of California Press.

Kopytoff, I. 1986 "The cultural biography of things: commoditization as process. In A. Appadurai (ed.), The social life of things: commodities in cultural perspective, pp. 64-91. Cambridge: Cambridge University Press.

Kozinets, R.V. and J. Handelman. 1998 "Ensouling consumption: a netnographic exploration of the meaning of boycotting behavior." In J.W. Alba and J.W. Hutchinson (eds.) Advances in Consumer Research, pp. 47580. Provo UT: Association for Consumer Research.

Latour, B. 2005 Reassembling the social: an introduction to actor-networktheory. New York: Oxford University Press. 
Lekakis, E. J. 2013 Coffee activism and the politics of fair trade and ethical consumption in the global north: political consumerism and cultural citizenship. New York: Palgrave Macmillan.

Lopez, R. 2002 Chocolate: the nature of indulgence. New York: Harry N. Abrams in association with the Field Museum, Chicago.

Luetchford, P. 2011 “Coffee." In M. Warrier (ed.), The politics of fair trade: a survey, pp.116-22. London: Routledge.

Man, C. M. D. and A. A. Jones (eds.) 2000 Shelf-life evaluation of foods, $2^{\text {nd }}$ ed. Gaithersburg MD: Aspen.

Martin, A. V. 2000 "Chocolate confectionery." In C. M. D. Man and A. A. Jones (eds.), Shelf-life evaluation of foods, $2^{\text {nd }}$ ed., pp. 169-81. Gaithersburg MD: Aspen.

Maurer, B., T. C. Nelms and S. C. Rea 2013 “'Bridges to cash': channeling agency in mobile money." Journal of the Royal Anthropological Institute 19 (1): 52-74.

McCabe, M. 2014 “Configuring family, kinship and natural cosmology: branding pet food." In R. Denny and P. Sunderland (eds.), Handbook of anthropology in business, pp. 362-78. Walnut Creek, CA: Left Coast Press.

Mills, M. A. 2013 "The opposite of witchcraft: Evans-Pritchard and the problem of the person." Journal of the Royal Anthropological Institute 19 (1): 18-33.

Mintz, S. W. 1996 Tasting food, tasting freedom: excursions into eating, culture and the past. Boston: Beacon Press.

Moeran, B. 1997 Folk art potters of Japan: beyond an anthropology of aesthetics. Honolulu: University of Hawaii Press.

Off, C. 2006 Bitter chocolate: investigating the dark side of the world's most seductive sweet. New York: Random House Canada.

Oliveira, P. 2012 "Ethnography and co-creation in a Portuguese innovation consultancy: wine branding research as an example." Journal of Business Anthropology 1 (2): 196-217.

Payson Center for International Development, Tulane University 2011 "Final report: oversight of public and private initiatives to eliminate the worst forms of child labor in the cocoa sector in Cote d'Ivoire and Ghana." Report to the US Congress, March 31, 2011. www.child-laborpayson.og/Tulane\%20Final\%20Report.pdf. Accessed 13 August 2013.

Radcliffe-Brown, A. R. 1940 “On joking relationships.” Africa 13: 192-210.

Raghavan, S. and S. Chatterjee 2001 "Slaves feed world's taste for chocolate: captives common in cocoa farms of Africa." Milwaukee Journal Sentinel, 24 June 2001. Retrieved 9 April 2013.

Reichman, D. R. 2011 The broken village: coffee, migration, and globalization in Honduras. Ithaca: Cornell University Press. 
Satre, L. J. 2005 Chocolate on trial: slavery, politics, and the ethics of business. Athens OH: Ohio University Press.

Sherry, J. F., Jr. and R. V. Kozinets 2007 "Comedy of the commons: nomadic spirituality and the Burning Man festival." In R. W. Belk and J. F. Sherry, Jr. (eds.), Consumer Culture Theory, pp. 119-47. San Diego CA: JAI Press.

Slater, D. 1997 Consumer culture and modernity. Cambridge: Polity Press.

Sunderland, P. L. and R. M. Denny 2007 Doing anthropology in consumer research. Walnut Creek CA: Left Coast Press.

Terrio, S. J. 2000 Crafting the culture and history of French chocolate. Berkeley: University of California Press.

The Economist 2001 "Slave ships in the $21^{\text {st }}$ century? Child slavery in West Africa." The Economist (US) 21 April 2001: 3. Academic OneFile. Web. 6 April 2013.

Watson, J. L. (ed.) 1997 Golden arches east: McDonald's in East Asia. Stanford: Stanford University Press.

Yeoman, I. 2011 "The changing behaviours of luxury consumption." Journal of Revenue and Pricing Management 10 (1): 47-50.

Maryann McCabe, Ph.D., is a cultural anthropologist who has been engaged in market research for over 20 years. She is founder and principal of Cultural Connections LLC, which helps corporations, advertising agencies and other organizations develop brand positioning and market segmentation. She is also Senior Lecturer at the University of Rochester, Department of Anthropology, where she has been teaching courses on business anthropology, entrepreneurship and sustainability for fifteen years. She has published many articles on US consumer culture in peer-reviewed journals including Human Organization, Journal of Consumer Culture, International Journal of Business Anthropology, and the Journal Business Anthropology. She may be reached at mm@cultureconnex.com and www.cultureconnex.com 